\title{
A Critical Study on the State of Globalization Today, Focusing on Selected Current Global Issues
}

\author{
Rico Timotius Gotama, Adrian Tan Hock Seng, Mehdi Tasaloti, Reynold \\ Tom Fernandez
}

To Link this Article: http://dx.doi.org/10.6007/IJARBSS/v11-i11/11676

DOI:10.6007/IJARBSS/v11-i11/11676

Received: 23 September 2021, Revised: 28 October 2021, Accepted: 10 November 2021

Published Online: 24 November 2021

In-Text Citation: (Gotama et al., 2021)

To Cite this Article: Gotama, R. T., Seng, A. T. H., Tasaloti, M., \& Fernandez, R. T. (2021). A Critical Study on the State of Globalization Today, Focusing on Selected Current Global Issues. International Journal of Academic Research in Business and Social Sciences, 11(11), 2111-2130.

Copyright: (c) 2021 The Author(s)

Published by Human Resource Management Academic Research Society (www.hrmars.com)

This article is published under the Creative Commons Attribution (CC BY 4.0) license. Anyone may reproduce, distribute, translate and create derivative works of this article (for both commercial and non0-commercial purposes), subject to full attribution to the original publication and authors. The full terms of this license may be seen

at: http://creativecommons.org/licences/by/4.0/legalcode

Vol. 11, No. 11, 2021, Pg. $2111-2130$

Full Terms \& Conditions of access and use can be found at http://hrmars.com/index.php/pages/detail/publication-ethics 


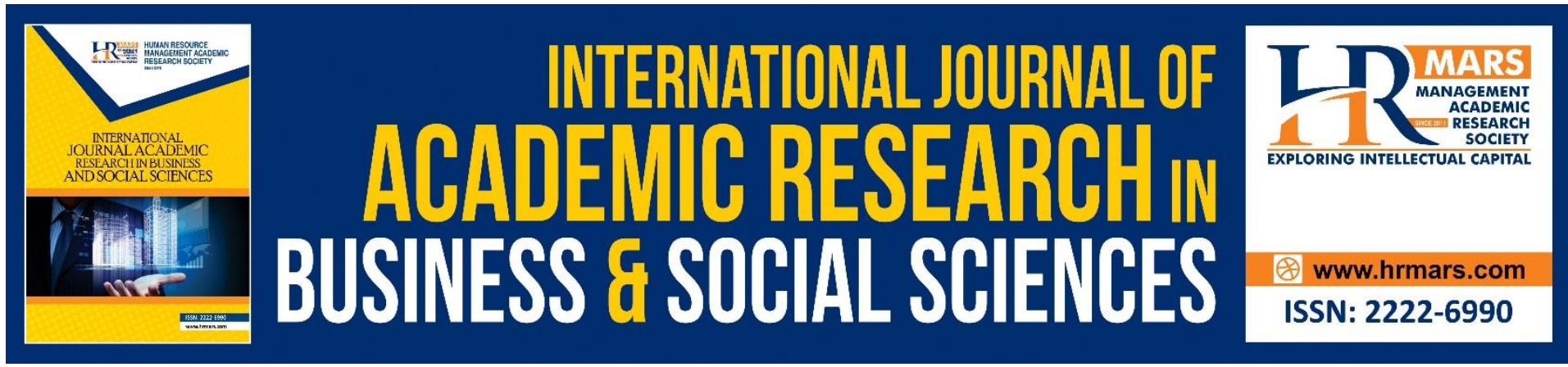

\title{
A Critical Study on the State of Globalization Today, Focusing on Selected Current Global Issues
}

\author{
Rico Timotius Gotama ${ }^{1}$, Adrian Tan Hock Seng ${ }^{2}$, Mehdi \\ Tasaloti², Reynold Tom Fernandez ${ }^{2}$ \\ ${ }^{1}$ Postgraduate Student, Faculty of Business, Communications and Law, INTI International \\ University, Malaysia, ${ }^{2}$ Senior Lecturer, Faculty of Business, Communications, and Law, INTI \\ International University, Malaysia.
}

\begin{abstract}
The purpose of this study is to discuss if globalisation will ever be a trusted concept, and to see if there is a possibility where globalisation will make the world perceive its benefits more than its failures. The importance of this study is to explain the origin and the rise of globalization in the world. Furthermore, the study examined the effects of globalisation on global warming and energy consumption. It also investigated the effect of globalisation on climate change. Our finding shows that the effect of globalisation will never be a trusted concept, since it will never be possible for the world to perceive globalisation mainly on its benefits rather than failures.
\end{abstract}

Keywords: Globalisation, Global Warming, Technology Development.

\section{Background of Research}

According to Griffin and Pustay (2020), globalisation is the incorporation of country-states, technology, and the markets that is unalterable, which permit people, enterprises, and country-states to move quicker, at lower cost, deeper, and at greater distance around the world than any previous time. From an economic perspective, globalisation may be defined as the increasingly economic trades integration in services and goods across border that includes international financial flow, the vast and swift spread of technologies between nations (Heimberger, 2020).

This has been a global issue since there is an argument that globalisation only fulfil the interest of the world when everything is perfect. Globalisation is a phenomenon that is related to economic systems, financial, economic, political, cultural, technological, sociological, ecological, geographic and markets. Therefore, it influences social and cultural elements as well. Specific needs based on region, the timings to act, and collaborative network are difficult to achieve. Since the world needs to cooperate and do consensus. However, if there is a discussion regarding fulfilling interest, each country has its own special needs, and this makes it uneasy to be "just" in globalisation (Leal, Caetano and Marques, 2021).

One of the globalisation purposes is to help increase the opportunity for enterprises to optimise their core competency, which is the main strength of the company's operations. In 
the hope to escalate its revenues and leading to higher profits (Griffin and Pustay, 2020). This paper discusses if whether globalisation will never be a trusted concept, to see if there is a possibility where globalisation will make the world perceive its benefits more than its failures. The evaluation uses the context of developed, developing, and less developing countries in general without mentioning any specific name of the country.

To put matters into perspective, this is a conceptual paper where it incorporates the past knowledge from previous literatures within the scope of relevant topics. While it does not utilise original data, it produces another work in a different context and contribute to fill the knowledge gaps (Wu and Furuoka, 2020).

\section{Problem Statement}

Globalisation is a phenomenon that becomes the foundation on the creation of global bloc such as the Group of 20 (G20). A group of the most industrialised and developing economies that gather together and discuss international economic and financial stability, they contribute more than 80 percent of the world gross domestic product (GDP). It was found to abolish trade barriers and create financial reforms (Wade, 2020).

Globalisation enables everyone to access almost anything across the world, starting from food, music, art, information, etc. The access is provided by the multinational corporations (MNCs) that exists due to globalisation allows companies to expand into foreign countries (Ahmad and Sood, 2019). The world is sharing knowledge and technologies that allow faster innovation, since everyone is connected (Ahmad and Sood, 2019).

Globalisation enable ventures to create global supply chain, assist each other and become inter-dependent on each other, designing plan for the cheapest way to produce products and services, lowering cost of production (Ali and Gurd, 2020). Global competition forces firms to compete, making affordable product and services variation for consumers to enjoy. In return, supporting everyone by making everything become more affordable (Ahmad and Sood, 2019).

Globalisation forces companies to do international recruiting, to tackle the challenges from time zones, culture, language, legal, tariff, and competition barriers. Globalisation has been assisting to provide more job opportunities for more people, especially in developing countries. However, it also carries a risk of job losses since companies would choose to downsize for greater profit by hiring less labours, contradicting to the main purpose (Rodríguez-Sánchez et. al., 2020).

Some studies conducted by González, Cortés-Sancho, Murcia, et. al. (2020); Winter-Ebmer, Grübl and Lackner (2020); Pieters and Rawlings (2020) discovered that children from unemployed staffs may influence the children's well-being and progress in the long-term. Some may find it difficult to obtain higher education and making them have lesser opportunity to be successful in the labour market.

The influence of employment rate and Foreign Direct Investment (FDI) in economic, technological development, environmental global climate change, and politics in the current world today toward globalisation still require further discussion. There are not many literatures that concurrently criticises globalisation in relation to economical, technological, environmental, and politics. Majority would only take the discussion independently (Ulucak, Danish and Khan, 2020; Gozgor, Mahalik, Demir, et. al., 2020; Paterson and P-Laberge, 2017; Cui, 2020; Lomborg, 2020). In most cases, their discussions on all these areas may only explicitly emphasize on some elements, while the rest may not be addressed in sufficient detail. 
Thus, further research on globalisation is required. This study may provide aid to further improve the academic understanding and expand the critiques regarding globalisation phenomenon. Current study explains globalisation in the scope of economic, technological development, environmental global climate change, and politics by putting more intensity on the environmental and technological influences.

\section{Research Questions}

RQ1: Will the economy have a significant influence on globalisation?

RQ2: Will technological developments have a significant influence on globalisation?

RQ3: Will environmental global climate change have a significant influence on globalisation? RQ4: Will politics have a significant influence on globalisation?

\section{Research Objectives}

RO1: To find out whether economy has a significant influence on globalisation

RO2: To find out whether technological development has a significant influence on globalisation.

RO3: To find out whether environmental global climate change has a significant influence on globalisation.

RO4: To find out whether politics has a significant influence on globalisation.

\section{Literature Review \\ Dependent Variable (DV) \\ Globalisation}

The term "Globalisation" existed for the first time in 1940 which focused on economics and politics, while it was already historically implemented in 1492 when Christopher Columbus discovered America (Jackson, 2020). In 1961, one magazine utilised the globalisation term on economic reformation of Spain. Then, Theodore Levitt, the marketing professor from Harvard Business School, became one of the first scholars who defined it as the expansion of corporation around the globe. Economically, it is the concurrent sales and marketing of similar products and services all around the world (Castañeda and Shemesh, 2020). This was echoed by the World Health Organisation (WHO) that defined it as the acceleration of interdependence and inter-linked between people and countries by opening the international borders. It encourages the flow of capital, goods, services, people, ideas, institutions, and policies to access opportunities from cross-border movements (Jackson, 2020).

Levitt opined that "globalise" would be beneficial for firms by standardising their products and enlarge geographically, then specialise on local product. He argued that embracing globalisation is necessary to improve the entire performance and to develop technology upgrade (Castañeda and Shemesh, 2020). Jackson (2020) stated that the influence of globalisation on the world of economy have been advantageous in the view of technology transfer, low-cost production on labour, which also support welfare. Castañeda and Shemesh (2020) also mentioned that globalisation helps to spread the capitalism ideology. According to Novák (2020), globalisation aids in developing and advancing technologies that leverage the swiftness on exchanging financial, transport, information, etc. Globalisation provides huge advantages and probably even greater disadvantages.

Previous studies have established the link of globalisation as a phenomenon with other factors. Castañeda and Shemesh (2020) concluded that there is positive relationship between globalisation towards economy and politics. Novák (2020) found positive relationship 
between globalisation towards economy, technology, and environment. Paterson and PLaberge (2017) exhibit the links between globalisation towards politics, economy, and environment. Gozgor et. al (2020) found a positive relationship between globalisation towards economy and the environment.

\section{Independent Variables (IVs) \\ Economy}

This paper aims to uncover if the economy has a significant influence on globalisation, and henceforth a research question was developed. This study will discuss on the economy and its relation to globalisation.

Economy is among the main reasons for globalisation. Countries and firms would embrace globalisation to improve their economic situation and gain higher profitability (Paterson and P-Laberge, 2017). Especially for nations within the East Asian region, where most are developing their economy. Allowing the influence of globalisation would enable these states to hasten their development to reach better conditions (Cui, 2020).

Jobs are being displaced by the MNCs from the high costs developed countries, to the lower cost in developing nations. Leading to less job opportunities in the developed nations (Radović-Marković, Brnjas and Simović, 2019). MNCs outsource overseas for cheaper labour to minimise expenses, which largely does not help in developing the economy (Heimberger, 2020).

As stated by Makengo (2021), globalisation is an option to leverage the economy of the country. Particularly, when countries are facing recession, they need to collaborate and work together to lessen the negative influence on the economy. Since the nature of globalisation where the economy of the whole world becomes inter-dependent on each other, the economic condition of one country would also be influencing the others (Jackson, 2020). According to Maclsaac and Duclos (2020), globalisation enables the economic integration between nations on their geographical locations. It influences the economy for the regulations on trade, tariff, and also sanctions on trade. Researchers confirmed that the economy is one of the major drivers for globalisation (Novák, 2020; Radović-Marković et. al., 2021; Rodríguez-Sánchez et. al., 2020).

MNCs may expand into the developing countries only for profit, and not to share their technologies. They only help the economies through foreign direct investment (FDI) (Shahbaz, Muhammad, Shahzad, et. al., 2018).

\section{Technological Development}

One of the objectives of this exploration is to identify whether technological development has a significant influence on globalisation. Thus, technological development with relation to globalisation will be explained.

Globalisation requires people to have more skills that fit the progress of technologies. The development of programming, robotics, and artificial intelligence will displace many human jobs. The age of artificial intelligence (AI) is coming and the risk that automations will displace job opportunities is high. Even if there are more jobs to be created, these jobs may require more expertise and education, in which majority of people may not have access. (Abuselidze and Mamaladze, 2021). Around 47 percent of jobs in the United States is facing the risk of being occupied by machines in the next two decades (Hussein, Halimu and Siddique, 2020). While globalisation is supposed to help provide more job opportunities for more people, especially those in developing countries. The resources that are being accumulated from all 
over the world are utilised to develop technologies, and technologies are replacing human labours.

For example, the United States decided to spend even more capital and resources around US\$250 billion for its research in technology, manufacturing, semiconductor development, and subsidies for making chip and robot to maintain its position in the world's technology over the competition (Bloom, 2021). This may be viewed as a unilateral act over willingness to become better than the others. Unilateralism is to make a decision for one party without discussing with other related parties (Kerr, 2020). This increases the risk to humans obtaining job opportunity.

The production system at home and in host countries are different because of the diverse technology advancement in each country, which emerge another challenge due to inequality, is being reinforced by the digital divide between home and host countries even further from time to time (Nwofia and Aworinde, 2020). Globalisation enable the richer countries country to gain more profits and invest more in Research and Development (R\&D), enabling them to develop and utilise greater technology to operate even faster and stay competitive. These findings prove that globalisation has significant influence towards technology development.

\section{Environment}

On environment, this paper intends to divulge the significance of environmental global climate change on globalisation. Hence, the association of environmental global climate with globalisation is examined.

Globalisation is driving the economy to practice large-scale and quantity production, and global circulations of items. These are contrasting to resources and energy conservation or limiting greenhouse gasses (Leal et. al., 2021).

MNCs are producing items that uses micro-plastics, the consumers and the company that utilise these items would throw away into the oceans, contaminating the oceans, acidifying the waters, impacting everybody's economic and health every day. Over 200,000 Americans pass away each year due to pollution exposure (Gaille, 2018). This creates waste problems that leads to greenhouse gas emissions, global warming, air pollution etc. Depletion of natural resources, de-forestation, destruction of ecosystems, loss of biodiversity and big plastic pollution. (Shahbaz, Shahzad, Mahalik, et. al., 2017 and Shao, Tillaguango, Alvarado, et. al., 2021).

Uchoa (2019) discussed that global warming makes the gap between the world's poorest and richest become 25 percent larger. African countries GDP, such as in Niger and Mauritania are 40 percent less, India's GDP per capita was 31 percent lower in 2010, and Brazil was 25 percent lower. By utilising more energy, the richer countries produce more greenhouse gas emissions. Thus, energy and income inequalities are connected and increasing in tandem (Roberts, 2020)

Historical data shows that crops and people are healthier and more productive when the temperature is neither very hot nor very cold. Hence, the cold countries have been receiving the benefits from the warming due to the increase of mercury level, whereas the hotter nations are obtaining the penalty by being pushed even more from the ideal temperature (Uchoa, 2019).

As people become richer, they have more expenditure on transportation and luxury goods such as cars, planes, and boats. Transportation is one of the most consumptive energy categories. Since the higher income people utilise energy intensive goods, the energy gap escalates even quicker than income gap (Roberts, 2020). 
The top 10 percent consumes 187 times in fuels and operational vehicles than the bottom 10 percent, while the bottom 10 percent utilises only two percent of the final energy. As people are able to travel between borderless countries due to globalisation, more energies are being consumed and consequently degrade the environment even further (Oswald, Owen and Steinberger, 2020). One study found that as people do more trade, the environment suffers as well (Shao, Tillaguango, Alvarado, et. al., 2021).

\section{Politics}

Discussion on politics focuses on uncovering the influence of politics on globalization. The inquiry is if politics has a significant influence on globalisation. Consequently, the connection between politics and globalisation is being investigated.

In politics, less developed countries with weaker laws on employment would have to suffer from the developed countries, globalisation with the MNCs is more toward exploiting than supporting (Burlacu, Gutu and Matei, 2018). Policy makers need to make changes from fossil fuels into renewable energy (Uchoa, 2019). Governments from developed nations may need to impose laws and force the MNCs to assist the developing countries rather than exploiting. Polluting industries from developed nations transfer the emission from the home countries that do not allow them to contaminate the environment through their production, on to the developing nations with lower quality on the regulation, or in countries where the MNCs may easily bribe corrupt governments to allow them to keep operating with non-sustainable methods (Leal et. al., 2021).

According to Lomborg (2020), governments have been trying to address this issue through The Paris Agreement which the expected outcomes actually do not worth the cost. The agreement is to keep the global temperature from rising under 2 degrees celsius. However, the negotiation over the climate responsibility is not efficient, and the carbon reduction distribution is more expensive than the minimum cost for implementing it.

Developed nations are still struggling to achieve the target for sustainable environmental policies, it would be even harder for developing countries since they are still striving for economic stability. Many developing countries are by depending on foreign direct investment (FDI), they attract the FDI by lessening their tariff and laws for the MNCs to come and invest into the country (Leal et. al., 2021).

Countries are starting not to practice multilateralism by discussing and participating together on any matter. Instead, unilateralism has been rising. Every country would wish to keep developing themselves further. By adopting more unilateralism, every nation may only think of their own interest by focusing on developing the economy while neglecting nature, although the nature is important (Kerr, 2020).

\section{Underlying Theories}

The theory on globalisation has been commonly discussed in two different perspectives. First is from Christopher Columbus since 1492 (Jackson, 2020). The second is by Theodore Levitt in 1961 (Castañeda and Shemesh, 2020). Christopher Columbus is the fundamental process of globalisation from the European colonial. The globalisation is traversing culture and language barriers that defines political systems (Jackson, 2020). Theodore Levitt provides the theory of globalisation from the perspective of economics. The appearance of global market, where the world has been driven to converge into one sole universal force, which is technology. In order to communicate and travel without boundary (Kollarova, 2020). 
Prior studies have examined the elements that contribute to enterprises and nations for embracing globalisation, Rodríguez-Sánchez, González-Torres, Montero-Navarro, et. al. (2020) argued that globalisation makes the labour market become more competitive since the human resource talent may be obtained from anywhere. Jahan, Alrajawy, Ali, et. al. (2020) found that economies, technology, market expansion for companies are among the considerable factors to accept globalisation. Babenko, Kulczyk, Perevosova, et. al. (2019) discovered that globalisation allows trading technology e-commerce to help businesses and customers everywhere. Thus, all the previous literatures have found that globalisation may be investigated through the lens of economic, technological, resources, and market expansion.

Economy, knowledge and technology are three major advantages that may be obtained through globalisation, since the country may prosper and able to start living easier by utilising technology to assist them in their activities (Novák, 2020). This was echoed by Gozgor et. al. (2020), when globalisation promotes positive influence on the economy, it will lead to greater knowledge that may be derived from education, then the country may be able to produce skilled labours who may create the technology to further expand the economy in a more sustainable way.

This study leverages on the influence of contributing elements toward globalisation. Those factors identified in this research are economy, technological development, environment, and politics.

\section{Gaps in the Literature}

The gaps from the past literatures are identified and thoroughly reviewed in relation to Globalisation. They are summarised in Table 2.0.

Table 2.0 Literature Review on Globalisation 
INTERNATIONAL JOURNAL OF ACADEMIC RESEARCH IN BUSINESS AND SOCIAL SCIENCES Vol. 11, No. 11, 2021, E-ISSN: 2222-6990 (C) 2021 HRMARS

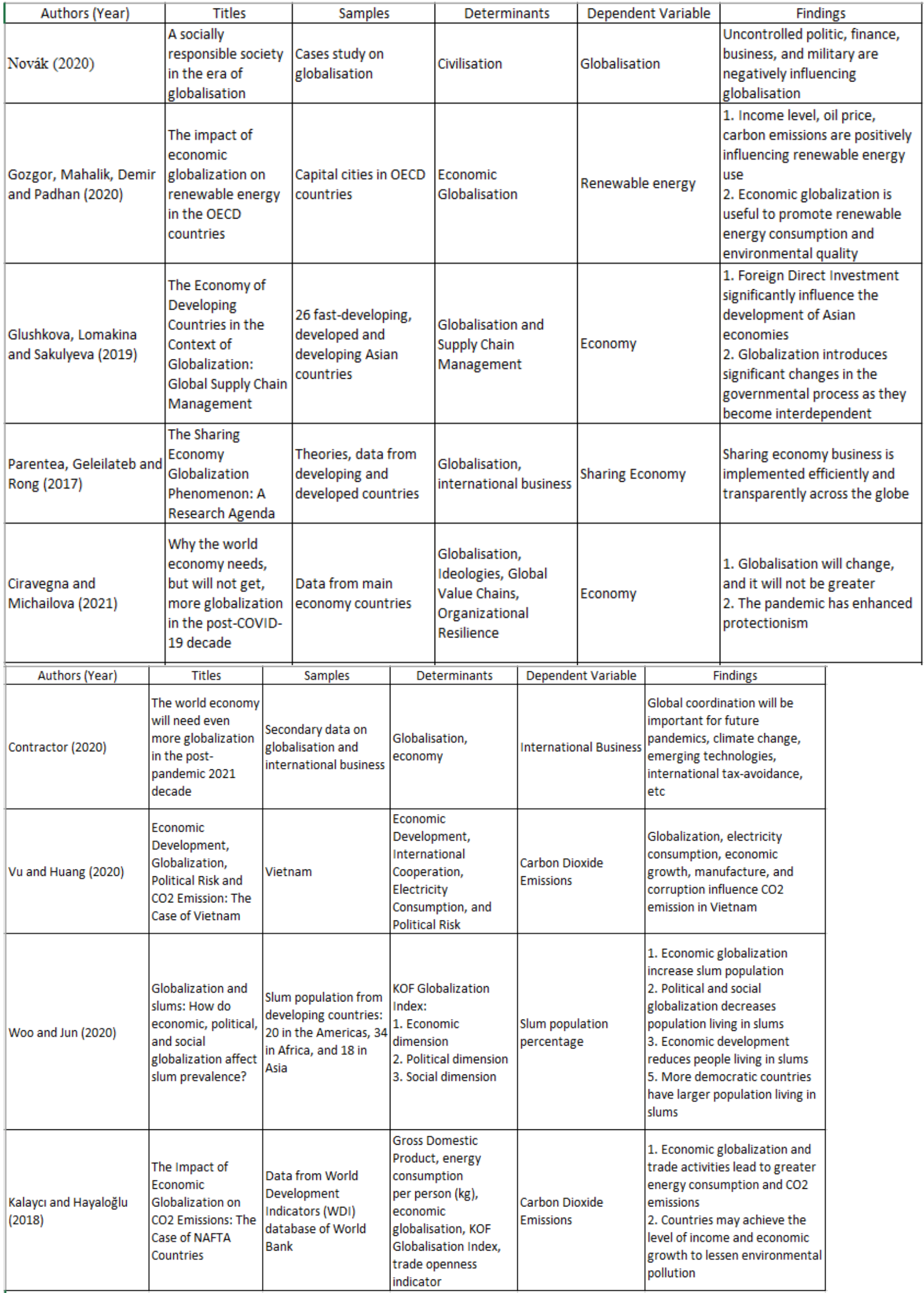


INTERNATIONAL JOURNAL OF ACADEMIC RESEARCH IN BUSINESS AND SOCIAL SCIENCES Vol. 11, No. 11, 2021, E-ISSN: 2222-6990 (C) 2021 HRMARS

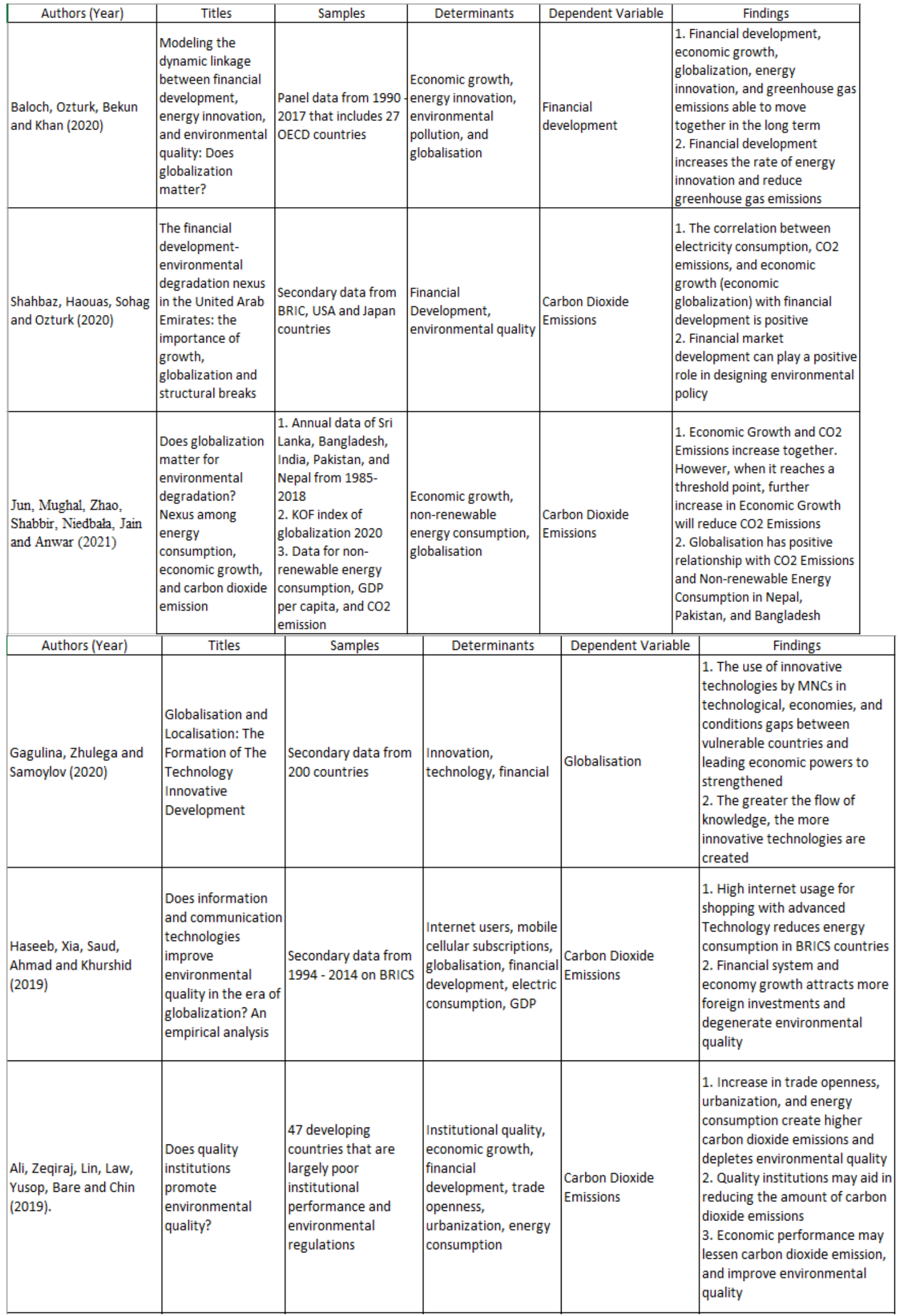


INTERNATIONAL JOURNAL OF ACADEMIC RESEARCH IN BUSINESS AND SOCIAL SCIENCES Vol. 11, No. 11, 2021, E-ISSN: 2222-6990 @ 2021 HRMARS

\begin{tabular}{|c|c|c|c|c|c|}
\hline Authors (Year) & Titles & Samples & Determinants & Dependent Variable & Findings \\
\hline $\begin{array}{l}\text { Hussein, Halimu and } \\
\text { Siddique (2020) }\end{array}$ & $\begin{array}{l}\text { The Future of } \\
\text { Artificial } \\
\text { Intelligence and its } \\
\text { Social, Economic } \\
\text { and Ethical } \\
\text { Consequences }\end{array}$ & Secondary data & $\begin{array}{l}\text { Social and ethical } \\
\text { consequences of Al, } \\
\text { Influence on Economy }\end{array}$ & $\begin{array}{l}\text { Artificial Intelligent } \\
\text { (AI) }\end{array}$ & $\begin{array}{l}\text { People and governments need } \\
\text { to accept technology than } \\
\text { resisting change, while guiding } \\
\text { the technology to serve than } \\
\text { challenge humanity }\end{array}$ \\
\hline
\end{tabular}

\section{Conceptual Framework}

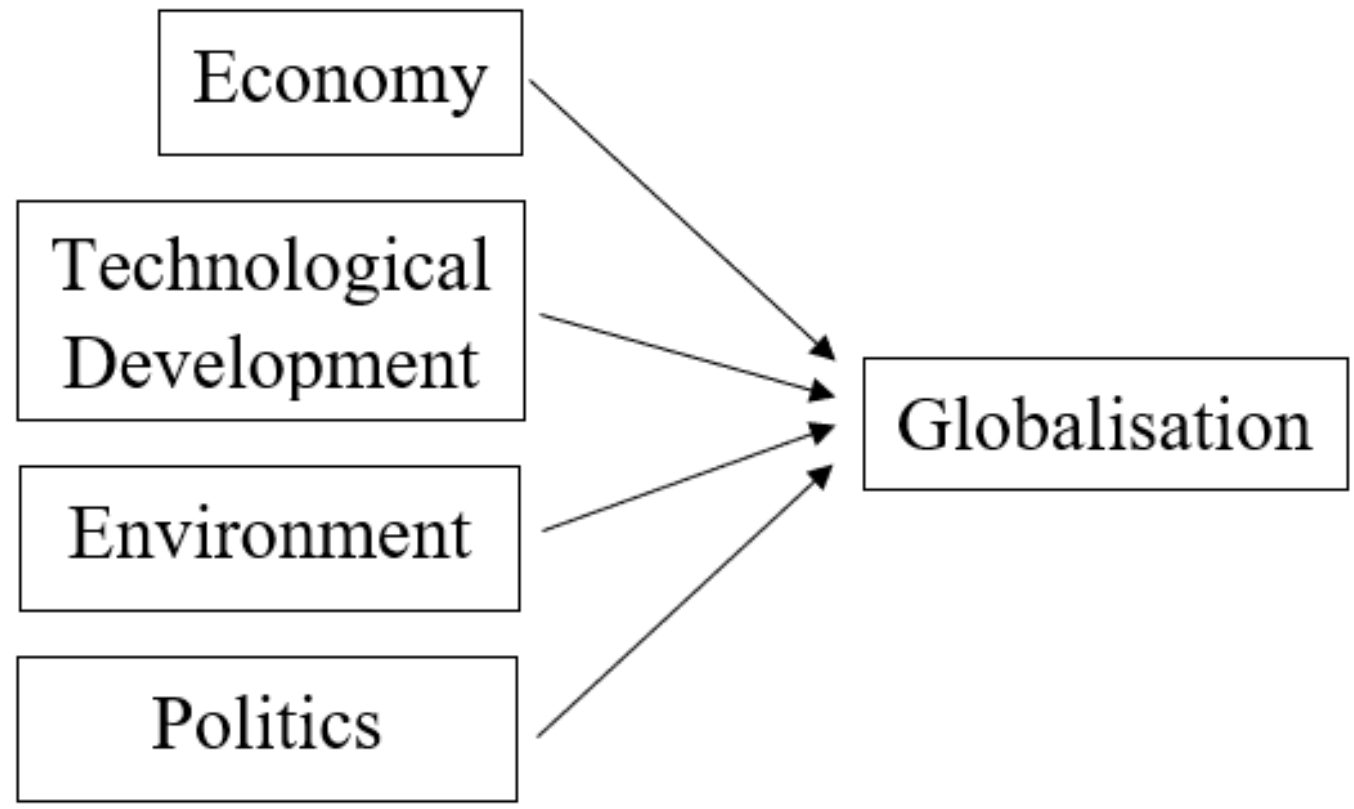

Figure 2.0 Conceptual Framework

Figure 2.0 provides the illustration where the aim of this study is to conclude whether globalisation may be perceived mainly from its benefits rather than failures. The DV is globalisation, and the influencing variables for the decision are economy, technological development, environment, and politics. 


\section{Research Method \\ Research Design}

This paper adopts Critical Realism as the research design. As stated by Sekaran and Bougie (2020) Critical Realism is the belief that is combined in external reality, which may be viewed by how the matters are alongside with the object. It renounces the perception where external reality may be consistently measured. Moreover, the observation on the phenomena will be constantly contingent on the interpretation. This is echoed by Wynn and Williams (2020), who argued that Critical Realism views the existing entities, including those that may only be observed indirectly. Theories regarding realities rely on individuals' beliefs and knowledge that are still open to questions. Critical Realism falls under the category of metatheory where it serves as a concept for general research to contribute to presenting explanation of social phenomenon than those presently exist with higher accuracy. It defines ontology, a more vigilant epistemology to explain the after effects by proper justifications.

This paper adopted critical realism to discuss globalisation as the approach allows the research to observe globalisation phenomenon in a way where it is being perceived as a reality that is relative to the individuals, and it is still fillable since the arguments are derived from secondary data and analysis from the writers. The results provided in on this paper in relation to globalisation are all established from the secondary data and evidence that may be justified, while the interpretations are more subjective to the researchers.

\section{Findings}

Benefits and Drawbacks

There are benefits and drawbacks found throughout the study. On one hand, the benefits are, the establishment of global blocs (Wade, 2020) such as World Bank, World Trade Organisation (WTO), International Monetary Fund (IMF) (Amadi, 2020) to facilitate movement of goods, services, and capital for trade and financial systems between nations. For instance, creating global supply chain to make prices become more affordable and to reduce poverty. Second, extend everyone's ability in purchasing any product or services worldwide through any accessible channels such as MNCs that offers its products and services to another country (Ahmad and Sood, 2019). Third, ability to request for foreign assistance should the need arise from any country (Eram, 2021). Fourth, it allows MNCs to enter new markets, provide job opportunities (Rodríguez-Sánchez, González-Torres, Montero-Navarro, et. al., 2020). Fifth, reduces tyranny government power since foreign governments may interfere or voice out their criticisms (Nikfar, 2020).

However, one the other hand, the drawbacks are first, MNCs may be overloaded due to the place, culture, language, time zone, and strategies at work (Rodríguez-Sánchez et. al., 2020), immigration policy for working visa, tariff and fees for export and import (Bound, Braga, Khanna, et. al., 2021), changes in regulations in employment and wages, the required capital to expand overseas (Radović-Marković et. al., 2019; Ahmad and Sood, 2019). Moreover, some countries may not gain the job opportunities for local people since those positions are taken by the overseas expatriates (Burlacu et. al., 2018).

Second, technology that has been both assisting and threatening workforce. Technology has been replacing the need for companies to hire human labours for simple tasks such as object lifting, counting money, and sharing information (Abuselidze and Mamaladze, 2021). The age of Artificial Intelligence (AI) is predicted to cause a huge job loss in the labour market. When more job will be created, higher level of expertise and competencies will be required as well, in which large number of people do not have access to them (Hussein et. al., 2020). 
Figure 1.0: Income from Artificial Intelligence (AI) software market worldwide (in billion USD)

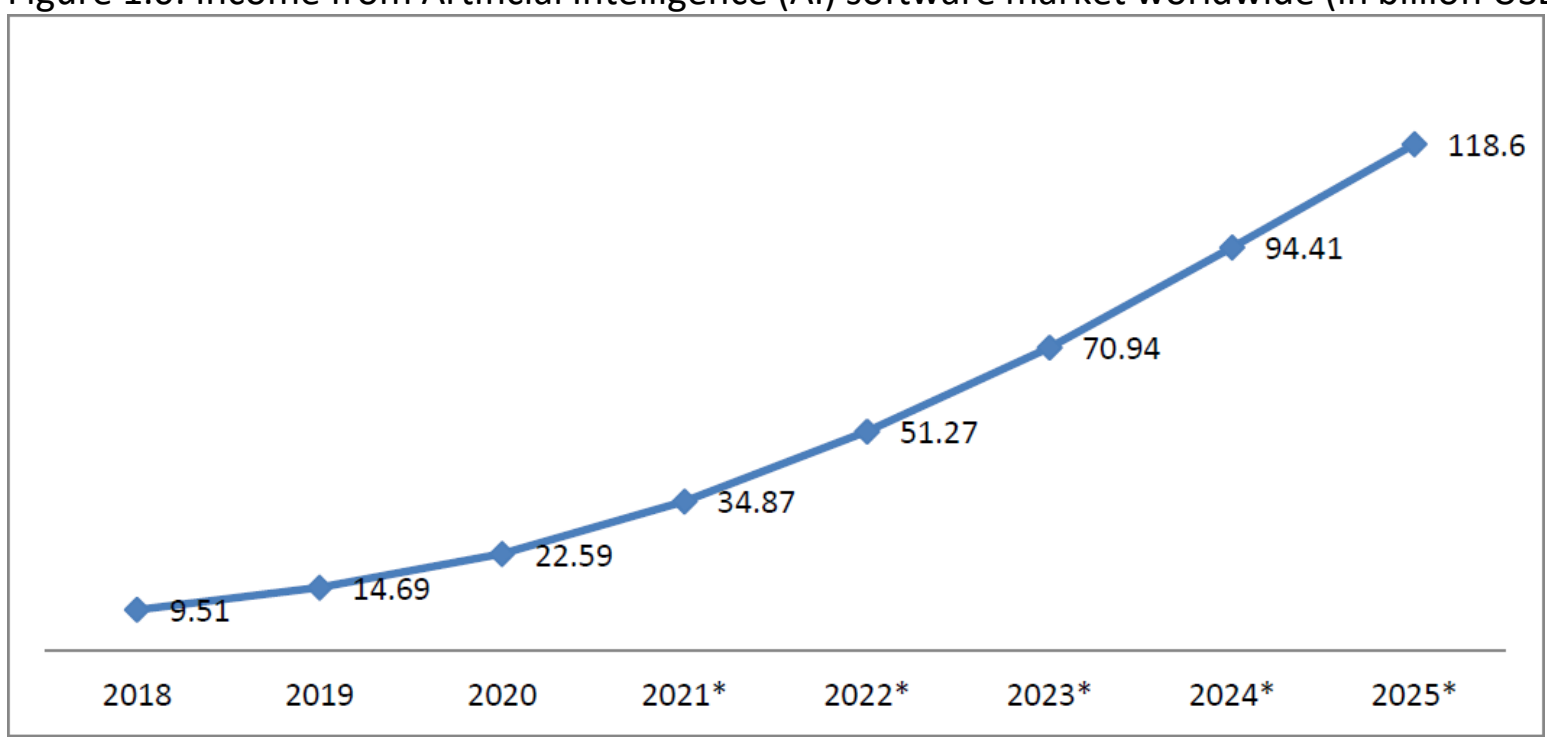

Source: Abuselidze and Mamaladze, 2021

Figure 2.0: Potential Job at Risk from Automation

\section{$\%$ of existing jobs at potential risk of automation}

Wave 1

(to early 2020s)

Wave 2

(to late 2020s)

Wave 3

(to mid-2030s)
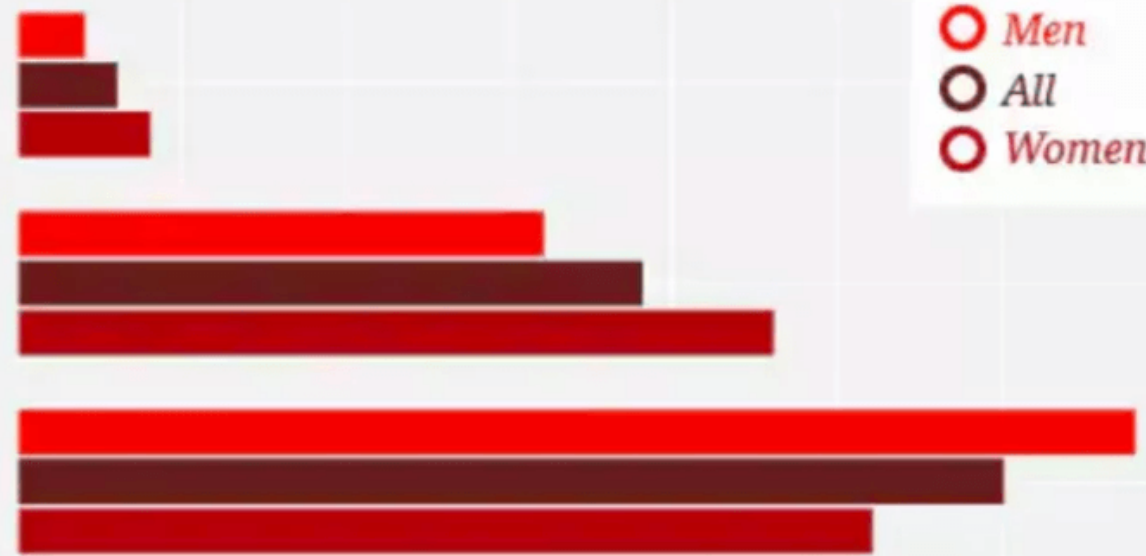

0

\section{$5 \%$}

$10 \%$

$15 \% \quad 20 \%$

Source: Fleming (2020)

The influence of such phenomenon will last for decades to come by reason of parents' unemployment does have influence on the children's long-term condition. A number of them may experience hardship in their education, minimising their chance of success in the labour market (González et. al., 2020; Winter-Ebmer et. al., 2020; Pieters and Rawlings 2020).

Globalisation's side effect is making countries to compare themselves even more, they compete on technology and risking job losses. This can be seen from U.S. perception on China as a threat and decided to compete against it (Bloom, 2021). Unilateralism has been growing for countries to become better than others. 
The Present Condition

The portion of resources being divided among the developing and developed countries are dissimilar, where 20 richest societies in the world uses circa 90 percent of the whole planet's resources every year (Gaille, 2018). Developed countries are gaining greater advantages than developing nations (Diffenbaugh and Burke, 2019). The smaller local businesses in the developing countries are being taken over by the MNCs from developed nations. All countries are relying on each other heavily, putting them at greater risk (Ahmad and Sood, 2019). MNCs are relocating the job opportunities from home countries to the developing countries for cheaper cost (Radović-Marković et. al., 2019), and avoiding taxes. Crimes are related to smuggling and human trafficking due to globalisation (Abugre and Anlesinya, 2019).

Globalisation on the environment

This paper would focus on global warming for environmental discussion. There are varieties of issues on the environment, some of which are global warming, greenhouse gas emissions, air pollution, natural resources being depleted, de-forestation, destruction of ecosystems, loss of biodiversity, big plastic pollution due to waste problem (Shahbaz et. al., 2017 and Shao, Tillaguango, Alvarado, et. al., 2021). Based on one-day data from Uchoa (2019), the distinction between world's poorest and richest have expanded by 25 percent as a result of global warming.

Global warming has been significantly decreasing productivity on developing nations with hotter climate, as the heat in those places has become unbearable. Colder and richer climate countries contribute much higher to the climate change by consuming more energies. While the hotter countries contributed at a very minimum level, although they received the highest influence (Uchoa, 2019).

Causes for Higher Energy Consumption

People with higher income, spent more on transportations and luxury goods (Oswald et. al., 2020). Transportation is among the highest energy consumptive product, and people would use even more energy intensive products since they can afford them (Roberts, 2020).

Figure 4.0: Elasticity and Energy Intensity 


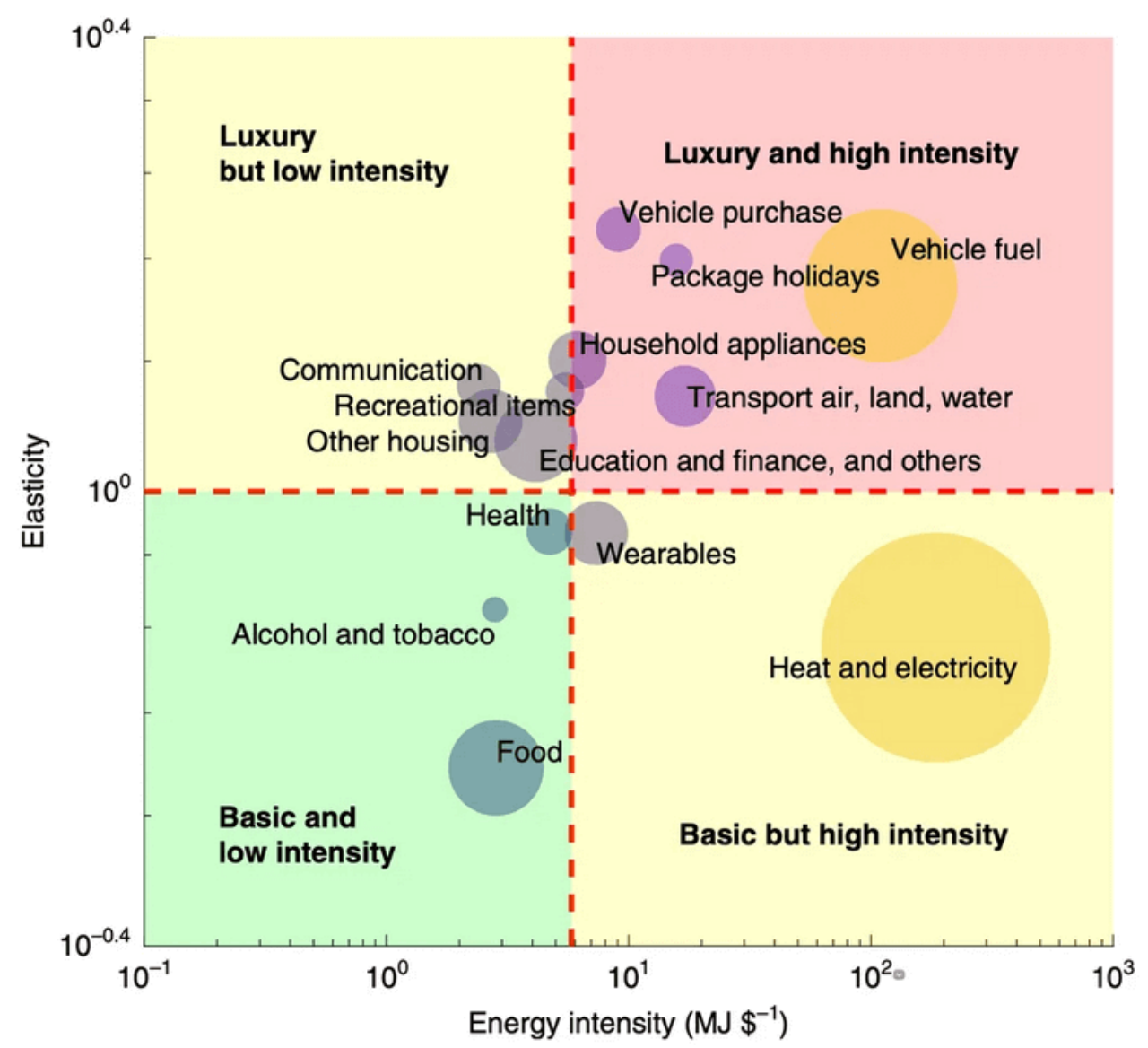

Source: Roberts (2020)

Some nations have made the commitment to become sustainable, although many others are still developing the economy (Leal et. al., 2021). Robert (2020) argued that one good method is for those with higher income to reduce their energy usage, since other mechanisms such as taxes and decarbonising may be more challenging to apply. However, those who hold the decision-making positions would place greater importance on the economy.

Large populations may be another reason for high energy consumption. In the case of China that needs more electricity and decided to use Yangtze River to open a hydro plant, was criticised for the damage to the habitats and food plains (Reuters, 2021).

There is a prediction that energy usage will raise by two fold in 2030, and three fold in 2050 (Oswald et. al., 2020). Shao, Tillaguango, Alvarado, et. al (2021) found that trade activities lead to vitiation of environmental quality. In another words, economic development sacrifices environmental health.

As stated by Burlacu et. al (2018) the developing and less developing countries have weaker regulations where MNCs may easily take that as an advantage for lower production cost. It can be argued that they are more on manipulating than giving aid to the nations. Industrialisation impoverish water and food resources, which cause many illnesses and allergies. Leal et. al (2021), industries that contaminate the environment move from developed nations transfer the emission to the developing nations that have lax regulations where they may operate without restriction, although their approaches may not be sustainable. 
Even when people are attempting to mitigate the carbon emission in the form of electric vehicles, almost 25 percent electricity is generated through burning coal. Therefore, the solution may not contribute much to decarbonisation (Lienert, 2021).

Activities from globalisation makes the temperature continuously rise and causes performance to be less efficient and effective. They become less productive, produce less, leading to less sales offering. Ultimately, lessening the enterprise's overall income (Burlacu et. al., 2018).

Khalil (2021) opined that attempt to address climate change is an expense and not an investment. Australia for example, target to have net zero emission by 2050.

\section{Governments Attempt}

Governments are attempting to address the climate change by way of The Paris Agreement. There is no balance between cost and outcomes. It is one method to maintain the global temperature to stay below two degrees Celsius. From 197 countries that agreed, only 17 of them have passed laws accordingly. It will cost greater than US\$50 trillion to lower the temperature under 3 degrees Celsius (Lomborg, 2020). The issue comes from the developing countries that need to concurrently consider the economic stability, from how they impose the tariff and laws on foreign companies that may not be in favour with addressing the climate change (Leal et. al., 2021).

Governments tend not to use the multilateralism approach by discussing and participating together on any matter (Kerr, 2020). They are solving their issues unilaterally, they only place emphasisz on their own interest to develop the economy in the short-term.

\section{Conclusion}

Economically, globalisation has been advantageous by developing the firms' core competencies. However, there are more failures in overall. Even though many things are considered for example, technology, economy, cultural diversity etc, the implementation of globalisation has made the environment to be less important compared to the economy. The MNCs improve their core competencies through globalisation generally utilise nonsustainable methods.

Globalisation enables firms and governments to accumulate resources from everywhere and develop-more advance technology. Technology benefiting the companies to perform better and stay competitive. Nonetheless, it leads to unemployment since firms need less human labour. Humans are being replaced by automation robots that can perform better than human, greater outputs, and more cost effective in the long-term. The rich will become richer and the poor become poorer.

The whole world ceaselessly creates greater technology and focus on developing the economyie while sacrificing nature. All these are displaying the failures of globalisation. Hence, globalisation will never be a trusted concept. Globalisation primarily giving only benefits may not be true or right.

\section{References}

Abugre, J. B., \& Anlesinya, A. (2019). Corporate Social Responsibility and Business Value of Multinational Companies: Lessons from a Sub-Saharan African Environment. Journal of African Business. 
Abuselidze, G., \& Mamaladze, L. (2021). The impact of artificial intelligence on employment before and during pandemic: A comparative analysis. Journal of Physics: Conference Series, pp. 1-10.

Ahmad, M. D., \& Sood, K. (2019). Determine the Management Efficiency in A Multinational Corporation (MNC) Based on Return of Capital (ROC). The Middle East International Journal for Social Sciences (MEIJSS), 1(4), pp. 71-78.

Ali, H. S., Zeqiraj, V., Lin, W. L., Law, S. H., Yusop, Z. Y., Bare, U. A. A., \& Chin, L. (2019). Do quality institutions promote environmental quality? Environmental Science and Pollution Research, 26, pp. 10446-10456.

Ali, I., \& Gurd, B. (2020). Managing operational risks through knowledge sharing in food supply chains. Wiley, pp. 1-10.

Amadi, L. (2020). Globalization and the changing liberal international order: A review of the literature. Research in Globalization, 2.

Babenko, V., Kulczyk, Z., Perevosova, I., Syniavska, O., \& Davydova, O. (2019). Factors of the development of international e-commerce under the conditions of globalization. SHS Web of Conferences, 65.

Baloch, M. A., Ozturk, I., Bekun, F. V., \& Khan, D. (2020). Modeling the dynamic linkage between financial development, energy innovation, and environmental quality: Does globalization matter? Business Strategy and the Environment, pp. 1-9.

Bloom, J. (2020). Will coronavirus reverse globalisation? [online]. Available at: https://www.bbc.com/news/business-52104978 [Accessed 14 July 2021].

Bougie, R., \& Sekaran, U. (2020) Research Methods for Business: A Skill Building Approach, 8th edition. New York: John Wiley \& Sons Inc.

Bound, J., Braga, B., Khanna, G., and Turner, S. (2021). The Globalization of Postsecondary Education: The Role of International Students in the US Higher Education System. Journal of Economic Perspectives, 35(1), pp. 163-184.

Burlacu, S., Gutu, C., \& Matei, F. O. (2018). Globalisation - Pros and Cons. Quality - Access to Success, 19, pp. 122-125.

Castañeda, E., \& Shemesh, A. (2020). Overselling Globalization: The Misleading Conflation of Economic Globalization and Immigration, and the Subsequent Backlash. Social Sciences, 9(61).

Ciravegna, L., \& Michailova, S. (2021). Why the world economy needs, but will not get, more globalization in the post-COVID-19 decade. Journal of International Business Studies.

Contractor, F. J. (2020). The world economy will need even more globalization in the postpandemic 2021 decade. Journal of International Business Studies.

Cui, Y. (2020). East Asian Integration under the Background of Escalating De-Globalization and Unilateralism: Challenges and Strategies. Journal of Asia-Pacific Studies, (38), pp. 154166.

Das, S., Kundu, A., \& Bhattacharya, A. (2020). Technology Adaptation and Survival of SMEs: A Longitudinal Study of Developing Countries. Technology Innovation Management Review, 10(6), pp. 64-72.

Diffenbaugh, N. S., \& Burke, M. (2019). Global warming has increased global economic inequality. Proceedings of the National Academy of Sciences.

Eram, M. E. (2021). How flood insurance empowers people facing extreme weather in Bangladesh. [online]. Available at: https://www.wfp.org/stories/bangladesh-floodinsurance-world-food-programme-hunger-un-development [Accessed 14 July 2021]. 
Fleming, S. (2020). A short history of jobs and automation. [online]. Available at: https://www.weforum.org/agenda/2020/09/short-history-jobs-automation/ [Accessed 14 July 2021].

Gagulina, N., Zhulega, I., and Samoylov, A. (2020). Globalisation and Localisation: The Formation of the Technology Innovative Development. Globalization and its SocioEconomic Consequences, 74.

Gaille, L. (2018). 19 Advantages and Disadvantages of Globalization. [online]. Available at: https://vittana.org/19-advantages-and-disadvantages-of-globalization [Accessed 14 July 2021].

Glushkova, S., Lomakina, O. and Sakulyeva, T. (2019). The Economy of Developing Countries in the Context of Globalization: Global Supply Chain Management. International Journal of Supply Chain Management, 8(1), pp. 876-884.

González, L., Cortés-Sancho, R., Murcia, M., Ballester, F., Rebagliato, M., Rodríguez-Bernal, C. L. (2020). The role of parental social class, education and unemployment on child cognitive development. Elsevier Espana, 34(1), pp. 51-60.

Gozgor, G., Mahalik, M. K., Demir, E., Padhan, H. (2020). The impact of economic globalization on renewable energy in the OECD countries. Energy Policy.

Griffin, R. W. and Pustay, M. W. (2020). International Business: A Managerial Perspective. 9th edn. Harlow: Pearson Education Limited.

Haseeb, A., Xia, E., Saud, S., Ahmad, A., \& Khurshid, H. (2019). Does information and communication technologies improve environmental quality in the era of globalization? An empirical analysis. Environmental Science and Pollution Research.

Heimberger, P. (2020). Does economic globalisation affect income inequality? A metaanalysis. World Economy, 43, pp. 2960-2982.

Hussein, B. R., Halimu, C., \& Siddique, M. T. (2020). The Future of Artificial Intelligence and its Social, Economic and Ethical Consequences. International Conference on Advances in Computing and Technology, pp. 17-19.

Jackson, E. A. (2020). Emerging Innovative Thoughts on Globalization amidst the Contageon of COVID-19. Munich Personal RePEc Archive.

Jackson, E. A. (2020). Emerging Innovative Thoughts on Globalization amidst the Contageon of COVID-19. Munich Personal RePEC Archive.

Jahan, S., Alrajawy, I., Ali, S. A., \& Martin, P. (2020). Analysing the Impact of Globalisation on Business Performance: Case of UAE Food Industry. International Journal for Quality Research, 15(2), pp. 665-678.

Jun, W., Mughal, N., Zhao, J., Shabbir, M. S., Niedbała, G., Jain, V., \& Anwar, A. (2021). Does globalization matter for environmental degradation? Nexus among energy consumption, economic growth, and carbon dioxide emission. Energy Policy, 153.

Kalaycı, C., \& Hayaloğlu, P. (2018). The Impact of Economic Globalization on CO2 Emissions: The Case of NAFTA Countries. International Journal of Energy Economics and Policy, 9(1), pp. 356-360.

Kerr, W. A. (2020). "Aggressive Unilateralism" - The New Focus of US Trade Policy. Journal of International Law and Trade Policy, 21(1), pp. 1-17.

Khalil, S. (2021). Glo Climate change: Why action still ignites debate in Australia. [online]. Available at: https://www.bbc.com/news/world-australia-57606398 [Accessed 14 July 2021].

Kollarova, D. (2020). Globalisation and its impact on the creation of sustainable points of purchase. Globalization and its Socio-Economic Consequences, 74. 
Leal, P. H., Caetano, R. V., \& Marques, A. C. (2021). Is the Relocation of Polluting Industries Prompted by FDI Flow and Stock, Globalisation, Corruption and Regulation? International Journal of Environmental Research and Public Health, 18, pp. 1-30.

Lienert, P. (2021). When do electric vehicles become cleaner than gasoline cars? [online]. Available at: https://www.theedgemarkets.com/article/when-do-electric-vehiclesbecome-cleaner-gasoline-cars [Accessed 14 July 2021].

Lomborg, B. (2020). Welfare in the 21st century: Increasing development, reducing inequality, the impact of climate change, and the cost of climate policies. Technological Forecasting and Social Change, 156.

Maclsaac, S., \& Duclos, B. C. (2020). Trade and conflict: trends in economic nationalism, unilateralism and protectionism. Canadian Foreign Policy Journal, 26(1), pp. 1-7.

Makengo, B. M. (2021). Covid-19's Impacts and the End of Globalization? Scientific Research Publishing, 9, pp. 212-233.

Nikfar, J. (2020). Globalization and future of power relations in the Arabic Middle-East: a case study of Egypt and Libya. Humanities and Social Sciences Communications, 7, pp. 1-9.

Novák, J. (2020). A socially responsible society in the era of globalization. SHS Web of Conferences, 74.

Nwofia, C. C., \& Aworinde, O. (2020). Economic Globalisation and Economic Growth Dynamics in Nigeria. Journal of Economics, Management and Trade, 26(7), pp. 1-15.

Oswald, Y., Owen, A., Steinberger, J. K. (2020). Large inequality in international and intranational energy footprints between income groups and across consumption categories. Nature Energy, 5, pp. 231-239.

Parentea, R. C., Geleilateb, J. G., \& Rong, K. (2017). The Sharing Economy Globalization Phenomenon: A Research Agenda. Journal of International Management.

Paterson, $\mathrm{M}$ and P-Laberge, X. (2017). Political economies of climate change. Wires Climate Change.

Pieters, J., \& Rawlings, S. (2020). Parental unemployment and child health in China. Rev Econ Household, 18, pp. 207-237.

Radović-Marković, M., Brnjas, Z., \& Simović, V. (2019). The Impact of Globalization on Entrepreneurship. Economic Analysis, 52(1), pp. 56-68.

Reuters. (2021). China's giant Baihetan hydro plant begins generating power. [online]. Available at:

https://www.freemalaysiatoday.com/category/world/2021/06/28/chinas-giantbaihetan-hydro-plant-begins-generating-power/ [Accessed 14 July 2021].

Roberts, D. (2020). Why rich people use so much more energy. [online]. Available at: https://www.vox.com/energy-and-environment/2020/3/20/21184814/climatechange-energy-income-inequality [Accessed 14 July 2021].

Roberts, D. (2020). Why rich people use so much more energy. [online]. Available at: https://www.vox.com/energy-and-environment/2020/3/20/21184814/climatechange-energy-income-inequality [Accessed 14 July 2021].

Rodríguez-Sánchez, J., González-Torres, T., Montero-Navarro, A., \& Gallego-Losada, R. (2020). Investing Time and Resources for Work-Life Balance: The Effect on Talent Retention. International Journal of Environmental Research and Public Health, 17, pp. 1-14.

Shahbaz, M., Haouas, I., Sohag, K., \& Ozturk, I. (2020). The financial developmentenvironmental degradation nexus in the United Arab Emirates: the importance of growth, globalization and structural breaks. Environmental Science and Pollution Research, 27. pp. 10685-10699. 
Shahbaz, M., Shahzad, S. J. H., Mahalik, M. K., \& Hammoudeh, S. (2017). Does globalization worsen environmental quality in developed economies? Munich Personal RePEc Archive, pp. 1-40.

Shao, J., Tillaguango, B., Alvarado, R., Ochoa-Moreno, S., Alvarado-Espejo, J. (2021). Environmental Impact of the Shadow Economy, Globalisation, Trade and Market Size: Evidence Using Linear and Non-Linear Methods. Sustainability, 13, pp. 1-20.

Shao, J., Tillaguango, B., Alvarado, R., Ochoa-Moreno, S., Alvarado-Espejo, J. (2021). Environmental Impact of the Shadow Economy, Globalisation, Trade and Market Size: Evidence Using Linear and Non-Linear Methods. Sustainability, 13, pp. 1-20.

Uchoa, P. (2019). Climate change is driving the wealth gap in more ways than we think. [online]. Available at: https://www.bbc.com/worklife/article/20190502-how-globalwarming-has-made-the-rich-richer [Accessed 14 July 2021].

Vu, T. V., \& Huang, D. C. (2020). Economic Development, Globalization, Political Risk and CO2 Emission: The Case of Vietnam. Journal of Asian Finance, Economics and Business, 7(12). pp. 21-31.

Wade, R. H. (2020). Rethinking the world economy as a two bloc hierarchy. real-world economics review, 92, pp. 4-21.

Winter-Ebmer, R., Grübl, D., \& Lackner, M. (2020). Intergenerational Transmission of Unemployment - Causal Evidence from Austria Centre for Economic Policy Research. Institute for Advanced Studies, pp. 1-26.

Woo, B., \& Jun, H. J. (2020). Globalization and slums: How do economic, political, and social globalization affect slum prevalence? Habitat International, 98.

Wu, Q., \& Furuoka, F. (2020). Corporate Environmental Performance and Corporate Financial Performance: A Conceptual Paper. Malaysian Journal of Business and Economics, pp. 271-288.

Wynn, D. E. Jr \& Williams, C. K. (2020). Recent Advances and Opportunities for Improving Critical Realism-Based Case Study Research in IS. Journal of the Association for Information Systems, 21(1), pp. 50-89. 